検討した。すなわち，実験 No. 1 と同一条件で溶離した䊚状白 土 $200 \mathrm{~g}$ を洗浄塔に入れ, 流速 $6.67 \mathrm{ml} / \mathrm{min}$ で流通式に上り水 洗浄，または希硫酸洗浄（硫酸濃度 $10.85 \mathrm{~g} / 100 \mathrm{ml}$ ) を行ない, 経時的に洗液を採取して， $\mathrm{Al}_{2} \mathrm{O}_{3}$ および $\mathrm{Fe}_{2} \mathrm{O}_{3}$ の含有量を分析 した。その結果を図6に示した。図6 より酸洗浄の場合は単なる 水洗浄に比較して，製品白土中に残留する $\mathrm{Al}_{2} \mathrm{O}_{3}$ 㧊よび $\mathrm{Fe}_{2} \mathrm{O}_{3}$ の含有量がすみやかに0に近づく。これより希硫酸洗浄の場合は 処理母液中に含まれている硫酸アルミニウムお打よび硫酸鉄（III）が 加水分解を起こさないまま洗浄除去されるものと判定される。と くにこの作用は硫酸鉄 (III) に対していちじるしい。多回式溶離の 場合にはこのよ弓な加水分解防止・除去作用が溶離処理と同時に 行われているものと推定される。

\section{$3 \cdot 4$ 循環多回式溶離方式の提案}

以上の実験結果にもとづき，図 7 のフローシートのよ5な循㻴 多回式溶離方式を提案したい。かくすれば在来法にくらべて得ら れる製品活性白土の活性が高く，しかも硫酸所要量が少なくてす み，また溶離処理の廃母液は硫酸アルミニウムなどの含有量が高 く, 逆に末反応硫酸の含有量が低くなる。さらに, 溶離後粒状白
土の洗浄過程に揖いて既報 ${ }^{3)}$ に述べた洗浄方法を行ならと置換洗

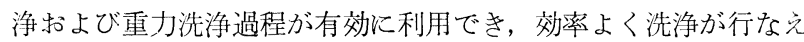
る。したがって，この循環多回式溶離方式により酸性白土の活性 化処理拉よび副産品の製造をきわめて経済的に行なうことができ る。

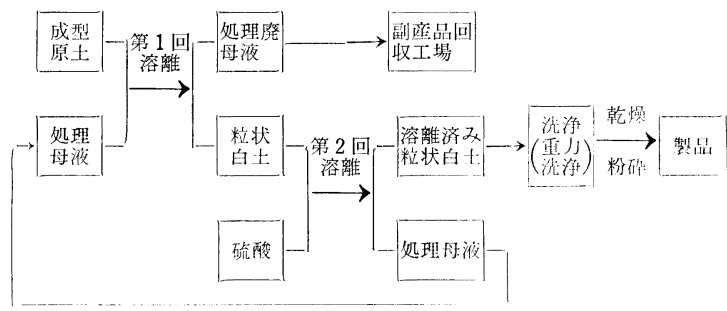

図 7 循環式多回溶離方式のフローシート

本研究飞際し, 東京工業大学資源化学研究所長 森川清教授拈 よび室蘭工業大学白崎高保教授には終始御懇切なる御指導を賜わ った。ここに深甚の謝意を表します。また，本研究に熱心に協力 された水沢化学工業（株）前野昌弘氏に感謝します。

\title{
グリシドアミドと置換フェノールとの塩基接触開環反応
}

(昭 和 40 年 10 月 27 日受理)

\author{
洒井鎮美・林銃 吾・石井 義 郎*1
}

ニトロベンゼンまたは $n$ ーブタノール中，ナトリウムフェノキシドまたはトリ nーブチルアミンを触媒 (C) としてグリシドアミ

ド（E）と置換フェノール (P) との反応速度を測定し，グリシドアミドの異常な反応性を検討した。

ナトリウムフェノキシドを触媒とする $n$-ブタノール中の反応は， $-\mathrm{d}[\mathrm{E}] / \mathrm{d} t=-\mathrm{d}[\mathrm{P}] / \mathrm{d} t=k_{2} C_{0}[\mathrm{E}]$ なる 2 次式に従い， $\alpha>0$ の 範囲で $\rho=-0.95$ であり， p-クロルフェノールとの反応の活性化ェネルギー扰よびェントロピーは $20.6 \mathrm{kcal} / \mathrm{mol}$ 抢よび -9.4 e. u./mol であり，これらの結果はフェニルグリシジルェーテルなど通常のエポキシドの反応と同様の遊離イオン機構で説明され る。しかし溶媒を二トロベンゼンとするとフェニルグリシジルェーテルあるいはスチレンの反応と異なり，反応は，上記の 2 次式 に従い， $\rho=-1.6$ となり，3 分子錯体機構あるいはェポキシドの酸素原子とフェノールの水素結合の関与する機構は適用できず, nーブタノール中の遊離イオン機構の場合と同じ挙動を示した。

トリーnーブチルアミンを触媒とする反応では，いずれの溶媒中でも， $\mathrm{d} P / \mathrm{d} t=0$ で，通常のエポキシドの第 3 アミンを触媒とする

反応と異なり，フェノールとェポキシドの $1: 1$ 付加生成物を生成せず，グリシドアミドの重合のみが起こった。

これらの結果はグリシドアミドのアミド置換基の強い電子吸引性によるエポキシドの異常反応として説明される。

\section{1 緒言}

エポキシドの塩基接触開壊反応は従来単純イオン機構，たと齐 ば Boyd ら怙よび Patat ら²によるとエポキシドに対するフェ ノールの付加反応は，フェノキシドイオンによるエポキシドの $S_{X} 2$ 攻撃と考号られてきた。しかし著者らはキシレン中トリ $n$ ブチルアミンを触媒とするフェニルグリシジルェーテルと安息香 酸またはフェノールとの反応 ${ }^{3,4)}$, ニトロベンゼン中ナトリウム フェノキシドを触媒とするフェニルグリシジルェーテルをるいは

*1 Shizuyoshi SAKaI, Jugo HAYASIII, Yoshio ISHII 名 古屋大学工学部：名古屋政下種区不老町。

1) D. R. Boyd, E. R. Marle, J. Chem. Soc., 105, 2117 (1914).

2) F. Patat, O. Boblester, J. Polymer Sci., 12, 489(1954).

3) 消㧣, 植田, 不井, 工化, 64, 2159 (1962).

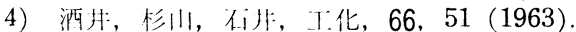

スチレンオキシドとフェノールとの反応 ${ }^{5,6)}$ などでは, 速度式は触 媒，エポキシド拉よび活性水素化合物のそれぞれの濃度の 1 次に 比例する見掛けの 3 次式で示され，活性水素化合物として置換つ ェノールを用いた場合のハメットの 值は正で, 単純イオン機構 の場合の速度式が 2 次で， $\rho$ 值が負となるのと対比的な結果とな り, 前述の反応に対しては遷移状態に触媒, 活性水素化合物抢よび エポキシドが関与する3 分子錯化合物機構を考えた7)。この機構と 類似の 3 分子機構がそののち Patat ら ${ }^{8)}$ によっても報告された。

従来は主として電子供与性の基を有するエポキシドについて研 究が行なわれてきたが，本報では電子吸引性の大きいアミド基が 置換基であるグリシドアミドの反応性について研究したもので,

5) 酒井, 杉山, 石井, 工化, 67, 333 (1964).

6) 説田, 酒井, 石井, 工化, 67, 1560, 1897 (1964).

7) 酒井, 石井, 工化, 61, 358, 1473(1958) ; 62, 413(1959).

8) E. Patat, Makromol. Chem., 37, 1 (1960). 
グリシドアミドがフェニルグリシジルェーテルなど従来のエポキ シドとかなり違った反応性を示すことが明らかとなった。

\section{2 実 験 方 法}

\section{$2 \cdot 1$ 試 料}

グリシドアミドは Payne らの方法 ${ }^{9}$ にしたがって, $35^{\circ} \mathrm{C}, \mathrm{pH}$ $7.3 \sim 7.5$ にてアクリロニトリルを過酸化水素水で酸化後, 少量 の二酸化マンガンを加兄て冷蔵庫中で 50 時間放置し，残存過酸 化水素を分解してのち，二酸化マンガンをロ別し， $25 \mathrm{mmHg}$ で ロータリーエバポレーターで濃縮し，アセトンを加光硫酸マグネ シウムで乾燥後アセトンを留去し，ついで減正蒸留し，デシケー ターに入れ，フリーザー中で保存した。沸点 $73 \sim 74^{\circ} \mathrm{C}$, 融点 33 $\sim 34^{\circ} \mathrm{C}$ 。エポキシ含有率 $97.2 \%$ 。触媒のナトリウムフェノキシ ドは，乾燥ベンゼン中フェノールと金属ナトリウムの反応で合成 し，塩酸滴定による純度 $99.9 \%$ のものを使用した。トリ $n$-ブ チルアミンは市肘品を蒸留後使用した。溶媒である ルおよびニトロベンゼンは常法で乾燥蒸留した。置換フェノール は市販品または常法で合成したものを精製し, 純度が $99.5 \%$ 以 上のものを使用した。

\section{$2 \cdot 2$ 反応速度測定法}

$200 \mathrm{ml}$ の丸底摺合わせ三つロフラスコにカキマゼ機，温度計 括よびリービッヒ冷却管をつけ, これに溶媒 $30 \mathrm{~g}$, グリシドアミ ド $0.5 \mathrm{~mol} / \mathrm{kg}$ を加光て溶解後, $0.5 \mathrm{~mol} / \mathrm{kg}$ のフェノールを加 光, 定温浴中で所定温度に保ったのち, 触媒を加えて反応を開始 させる。所定時間ごとに，リービッヒ冷却管を経て反応液を採取 し, 残存エポキシド量を塩酸・塩化マグネシウム法9)で, また残 存フェノール量を, カリウムメトキシド・ジメチルホルムアミド 法10)で測定した。

\section{3 実 験 結 果}

\subsection{Naフェノキシドを触媒とする $n$-ブタノール中の反応}

表 1 は乾燥 $n$-ブタノール中,ナトリウムフェノキシド $(\phi \mathrm{ONa})$ を触媒とする $p$ クロルフェノール $(\mathrm{P})$ とグリシドアミド $(\mathrm{E})$ の反応結果であり，この反応では $p$-クロルフェノールとグリシ ドアミドの減少量が等しく, グリシドアミドの完全な $1: 1$ モル 開環反応が起こり，重合反応は併起しないことを示している。ま た，エポキシドの減少量の対数より求めた見掛けの 1 次速度定数 は，エポキシドの変化率 $50 \%$ まで一定であり，また表 2 の クロルフェノールとグリシドアミドの仕込比を变えて測定したエ ポキシドに関する 1 次速度定数も, p-クロルフェノールの初濃度 に影響されずに一定であり，この反応は（1）式に従うことを示 している。

$$
\begin{aligned}
& v=-\frac{\mathrm{d}[\mathrm{E}]}{\mathrm{d} t}=-\frac{\mathrm{d}[\mathrm{P}]}{\mathrm{d} t}=k_{1}[\mathrm{E}]^{1}[\mathrm{P}]^{0} \\
& v=k_{1}[\mathrm{E}]=k_{2} C_{0}[\mathrm{E}]
\end{aligned}
$$

さらに図 1 の結果は $k_{1}$ が触媒濃度に比例することを示し， し たがって速度式（2）を得る。表 3 扣よび図 2 は

9) I. L. Jungnickel, E. P. Peters, A. Palar, F. J. Weiss, “Organic Analysis” vol, Interscience, Pub. Inc. (1953) p. 287.

10) S. J. Clark, "Quantitative Method of Organic Microanalysis", Buttercorths Scientific Publishers (1956) p. 213 ,
表 1 ブタノール中のp-クロルフェノールの爻伈

\begin{tabular}{|c|c|c|c|}
\hline $\begin{array}{c}\text { 反応㭙閏 } \\
\text { (min) }\end{array}$ & $\begin{array}{c}\text { エポキシ } \\
\text { ド残存量 } \\
(\mathrm{mol} / \mathrm{kg})\end{array}$ & $\begin{array}{c}\text { フェフ一 } \\
\text { 儿残价量 } \\
(\mathrm{mol} / \mathrm{kg})\end{array}$ & $\begin{array}{c}k_{1} \\
\left(\mathrm{hr}^{-1}\right) \\
\end{array}$ \\
\hline 0 & 0.5000 & 0.5000 & 0.220 \\
\hline 20 & 0.4646 & 0.4620 & 0.218 \\
\hline 40 & 0.4325 & 0.4301 & 0.222 \\
\hline 60 & 0.4003 & 0.4032 & 0.220 \\
\hline 80 & 0.3730 & 0.3570 & 0.215 \\
\hline 100 & 0.3487 & 0.3472 & 0.223 \\
\hline 120 & 0.3202 & 0.3265 & 0.219 \\
\hline 140 & 0.3005 & 0.3030 & 0.219 \\
\hline 160 & 0.2790 & 0.2830 & 0.210 \\
\hline \multirow[t]{2}{*}{180} & 0.2663 & 0.2696 & \\
\hline & & 平出 & 0.218 \\
\hline
\end{tabular}

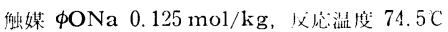

表 $2 n$-ブタノール中 $p$-クロルフェノールの反応速度に およぼすフェノール：エポキシド初濃度の影響 触媒 $\phi \mathrm{ONa}$ ，反纷温度 $74.5^{\circ} \mathrm{C}$

\begin{tabular}{ccccc}
{$[\mathrm{P}]_{0}$} & $(\mathrm{~mol} / \mathrm{kg})$ & 0.250 & 0.500 & 0.750 \\
{$[\mathrm{E}]_{0}$} & $(\mathrm{~mol} / \mathrm{kg})$ & 0.750 & 0.500 & 0.250 \\
\hline$k_{1}$ & $\left(\mathrm{hr}^{-1}\right)$ & 0.216 & 0.218 & 0.218
\end{tabular}

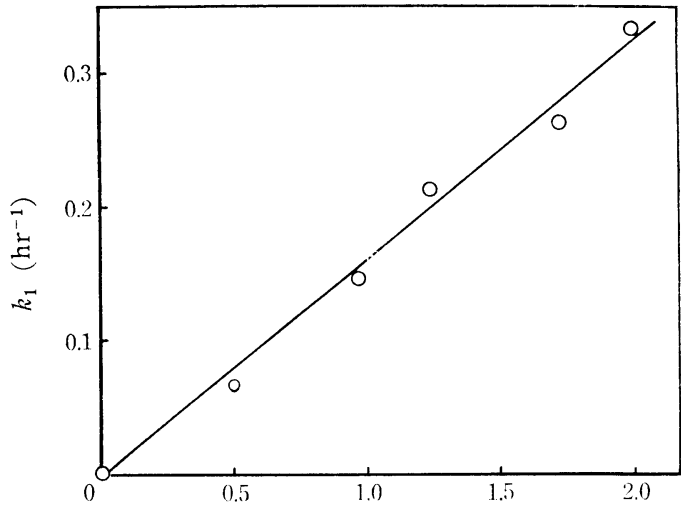

触媒濃度 $\left(10^{-2} \mathrm{~mol} / \mathrm{kg}\right)$

図 1 触 媒濃度 の 影響 nーブタノール中， pクロルフェノールの反応 反応温度 $74.5^{\circ} \mathrm{C},[\mathrm{P}]_{0}=[\mathrm{E}]_{0}=0.500 \mathrm{~mol} / \mathrm{kg}$, 佔媒 $\phi \mathrm{ONa}$

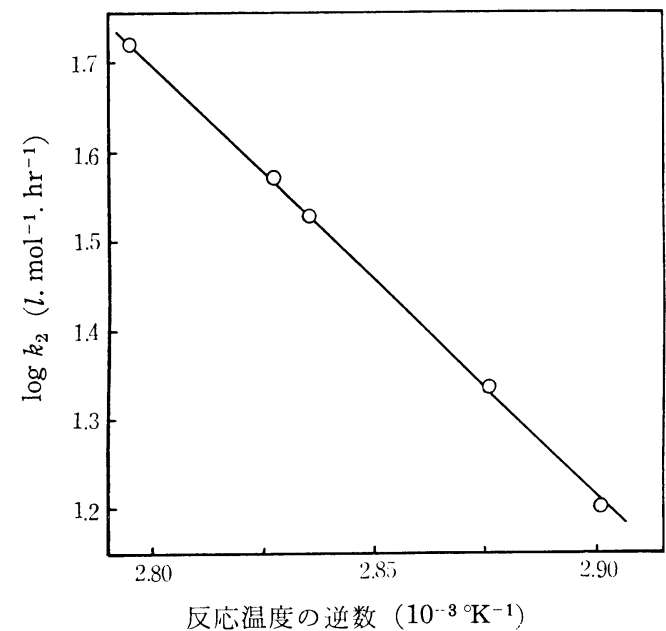

図 2 n-ブタノール中の $p$-クロルフェノール の反応の温度变化

$[\mathrm{P}]_{0}=[\mathrm{E}]_{0}=0.500 \mathrm{~mol} / \mathrm{kg}$, 做媒 $\phi \mathrm{ONa}$ 
ノールの反忍におよぼす温度の影響をホしたものであり, Arrhenius プロットより，見掛けの活性化エネルギーが $20.6 \mathrm{kcal} / \mathrm{mol}$, 扣よび活性化エントロピーが $-9.5 \mathrm{e} . \mathrm{u} . / \mathrm{mol}$ と計算される。

つぎに, 9 種の置換フェノールとグリシドアミドの反忘速度の 測定結果を表 4 および図 3 亿示す。置㩭 基定数 $\sigma$ 值が負の置換基を有するフェノ ールと, エポキシドの反応速度が Hammett 則に従わず， $\sigma<0$ の領域で上に凸 となる現象は土ポキシドの塩基接触遊離イオン機構による反応で 一般的に認められる現象である1,2 6)。しかし，フェニルグリシ ジルエーテルの反応(4) およびスチレンオキシドの反応(6) と異なり, グリシドアミドの場合は $\sigma>0.8$ の領域でも Hammett 则が成立. する。また $\sigma>0$ の籁囲での Hammett の $\rho$ 值は $-0.95 \pm 0.01$ となる。

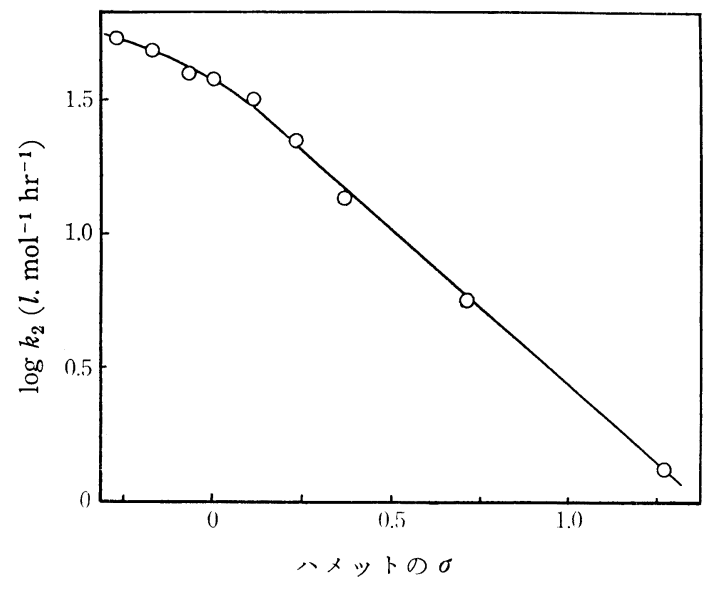

図3nーブタノール中置換フェノールの反応速度 $\left[\mathrm{P}_{0}\right]=\left[\mathrm{E}_{0}\right]=0.500 \mathrm{~mol} / \mathrm{kg}$, 船媒 $\phi \mathrm{ONa}$, 义心满度 $84.5^{\circ} \mathrm{C}$

\section{$3 \cdot 2$ トリーn-ブチルアミンを触媒とする反応}

ニトロベンゼン中, $0.020 \mathrm{~mol} / \mathrm{kg}$ のトリーnーブチルアミンを触 媒とし，pークロルフェノールとグリシドアミドを反応させた結果 を表 5 に示した。この結果は反応条件下 $p$ ークロルフェノールは 反応せず，エポキシドの雷合のみが起こることを示して扣り，こ のことは反応混合物の粘度が増大すること, 拉よび粘稠液体〜白 色固体の重合体を分離したことにより支持される。またグリシド アミドの消費速度定数は $0.188 \mathrm{hr}^{-1}$ となり， $3 \cdot 3$ で求めたフェ ノキシドイオンのグリシドアミドへの付加速度定数 0.590 より小 となり, また無触媒の場合の速度は 0.01 以下と测定され, また フェノール類が共存しなくても第三アミンを加えると重合が起こ ることが喼められたので, この重合反忘はフェノキシドイオンの 付加で重合が開始されるのではなく, 第三アミンのグリシドアミ ドへの付加反応が車合の開始過程に関与していることを示惨する もので岕ろら。

トリ n-ブチルアミンを触媒とする場合は，n-ブタノール中で もニトロベンゼン中の反㐫と同様に，エポキシドの重命だけが認 められ，スチレンオキシド执よびフェニルグリシジルェーテルと 全く異なった結果を得た。

\subsection{Naフェノキシドを触媒とするニトロベンゼン中の反応}

ニトロベンゼン中，ナトリウムフェノキシドを触媒とするグリ シドアミドと $p$ クロルフェノールの反応の絬果を表 6 に示す。 また表 7 は p-クロルフェノール拉よびグリシドアミドの使用・E
表 3 ブタノール中の $p$-クロルフェノールの反応

$[\mathrm{P}]_{0}=[\mathrm{E}]_{0}=0.500 \mathrm{~mol} / \mathrm{kg}$, 触媒 $\phi \mathrm{ONa} 0.0125 \mathrm{~mol} / \mathrm{kg}$

\begin{tabular}{cccccc} 
反応温度 $\left({ }^{\circ} \mathrm{C}\right)$ & 70.5 & 74.5 & 79.5 & 80.5 & 84.5 \\
\hline 比 重 & 0.8056 & 0.8024 & 0.7983 & 0.7965 & 0.7942 \\
$k_{2}\left(l . \mathrm{mol}^{-1} \mathrm{hr}^{-1}\right)$ & 15.9 & 21.5 & 33.3 & 37.5 & 53.0
\end{tabular}

表 4 n-ブタノール中の置換フェノールの反応

$[\mathrm{P}]_{0}=[\mathrm{E}]_{0}=0.500 \mathrm{~mol} / \mathrm{kg}$, 触媒 $\phi \mathrm{ONa} 0.0125 \mathrm{~mol} / \mathrm{kg}$, 反応滥度 $74^{\circ} \mathrm{C}$ $p-\mathrm{CH}_{3} \mathrm{O} \quad p-\mathrm{CH}_{3} \quad m-\mathrm{CH}_{3} \quad(\mathrm{H}) \quad m-\mathrm{CH}_{3} \mathrm{O} \quad p-\mathrm{Cl} \quad m-\mathrm{Cl} \quad m-\mathrm{NO}_{2} \quad p-\mathrm{NO}_{2}$ $\begin{array}{lllllllll}54.6 & 49.0 & 40.8 & 38.5 & 33.8 & 21.7 & 13.8 & 5.78 & 1.39\end{array}$

表 5 ニトロベンゼン中トリ $n$-ブチルアミンを 触媒とするグリシドアミドの反応 触媒 $0.020 \mathrm{~mol} / \mathrm{kg}$, 应灾治度 $84.5 \mathrm{C}$

\begin{tabular}{ccccc} 
反応時問 $(\mathrm{min})$ & 0 & 30 & 60 & 90 \\
\hline$[\mathrm{E}](\mathrm{mol} / \mathrm{kg})$ & 0.5100 & 0.4185 & 0.3302 & 0.2654 \\
{$[\mathrm{P}](\mathrm{mol} / \mathrm{kg})$} & 0.5000 & 0.4998 & 0.5000 & 0.4999
\end{tabular}

表 6 ニトロベンゼン中の $p$-クロルフェノールの反応 触媒 $\phi \mathrm{ONa} 0.0125 \mathrm{~mol} / \mathrm{kg}$, 反応滥度 $85.0^{\circ} \mathrm{C}$

\begin{tabular}{|c|c|c|c|}
\hline $\begin{array}{l}\text { 区応封間 } \\
(\mathrm{min})\end{array}$ & $\begin{array}{c}\text { エポキシド残存量 } \\
(\mathrm{mol} / \mathrm{kg})\end{array}$ & $\begin{array}{c}\text { フェール残存量 } \\
(\mathrm{mol} / \mathrm{kg})\end{array}$ & $\begin{array}{c}k_{1} \\
\left(\mathrm{hr}^{-1}\right)\end{array}$ \\
\hline 0 & 0.4999 & 0.5000 & - \\
\hline 10 & 0.4814 & 0.4750 & 0.228 \\
\hline 20 & 0.4683 & 0.4671 & 0.197 \\
\hline 30 & 0.4507 & 0.4518 & 0.208 \\
\hline 40 & 0.4355 & 0.4340 & 0.207 \\
\hline 50 & 0.4217 & 0.4200 & 0.205 \\
\hline 60 & 0.4036 & 0.4035 & 0.214 \\
\hline 70 & 0.3887 & 0,3871 & 0.216 \\
\hline 80 & 0.3801 & 0.3735 & 0.206 \\
\hline \multirow[t]{2}{*}{90} & 0.3614 & 0.3641 & 0.217 \\
\hline & & 平 均 & $0.211 \pm$ \\
\hline
\end{tabular}

表 7 ニトロベンゼン中 $p$-クロルフェノールの反応速度 に拉よぼすフェノール：エポキシド初濃度の影響 触媒 $\phi \mathrm{ONa} 0.0125 \mathrm{~mol} / \mathrm{kg}$, 反心温度 $85.0^{\circ} \mathrm{C}$

\begin{tabular}{cccc}
{$[\mathrm{E}]_{0}$} & 0.600 & 0.500 & 0.400 \\
{$[\mathrm{P}]_{0}$} & 0.400 & 0.500 & 0.600 \\
\hline$k_{1}\left(h r^{-1}\right)$ & 0.218 & 0.211 & 0.216
\end{tabular}

ル比の影響を示した。表 6 抢よび表 7 の結果は, 本節の反応条件 下でもグリシドアミドはエポキシドの 1 次の速度式（1）に從5 ことを示し, 同一の反応条件下スチレンオキシド拉よびフェニル グリシジルェーテルが 2 次の速度式に従うのと異なっている。

図 4 は $k_{1}$ が触媒濃度の 1 次に比例し, 式 (2) が適用できる ことを示し， $k_{2}$ に対する反応温度の影響は表 8 扎よび図 5 のよ らになる。ニトロベンゼン中のグリシドアミドの滴定分析は, $n-$ ブタノール中の反応の場合より終点の判定が困難のため, 図 5 の

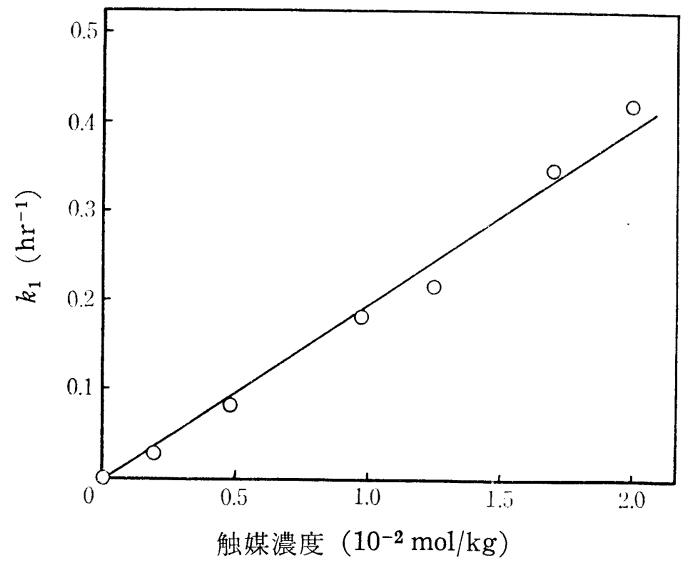

図 4 触媒濃度の影響

ニトロベンゼン中, $p$ クロルフェノールの反応, 反応温度 $85.0^{\circ} \mathrm{C}$ $[\mathrm{P}]_{0}=[\mathrm{E}]_{0}=0.500 \mathrm{~mol} / \mathrm{kg}$, 触媒 $\phi \mathrm{ONa}$ 
表 8 ニトロベンゼン中の $p$-クロルフェノールの反応

$[\mathrm{P}]_{0}=[\mathrm{E}]_{0}=0.500 \mathrm{~mol} / \mathrm{kg}$, 促媒 $\phi \mathrm{ONa} 0.0125 \mathrm{~mol} / \mathrm{kg}$

\begin{tabular}{lllll} 
反応温度 $\left({ }^{\circ} \mathrm{C}\right)$ & 74.5 & 79.5 & 85.0 & 90.0 \\
\hline
\end{tabular}

$\begin{array}{lllll}\text { 此 重 } & 1.2039 & 1.1985 & 1.1937 & 1.1854\end{array}$

$\begin{array}{lllll}k_{2}\left(l . \mathrm{mol}^{-1} \mathrm{hr}^{-1}\right) & 6.31 & 8.91 & 14.2 & 19.2\end{array}$

表 9 ニトロベンゼン中の置換フェノールの反尤

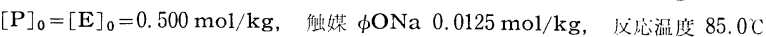

$\begin{array}{lllllllll}\text { 置 換 基 } \quad p-\mathrm{CH}_{3} & m-\mathrm{CH}_{3} & (\mathrm{H}) & m-\mathrm{CH}_{3} \mathrm{O} & p-\mathrm{Cl} & m-\mathrm{Cl} & m-\mathrm{NO}_{2} & p-\mathrm{NO}_{2}\end{array}$

$\begin{array}{lllllllll}k_{2}\left(l . \mathrm{mol}^{-1} \mathrm{hr}^{-1}\right) & 56.5 & 52.5 & 39.5 & 35.5 & 14.2 & 11.9 & 2.4 & (<0.5)\end{array}$

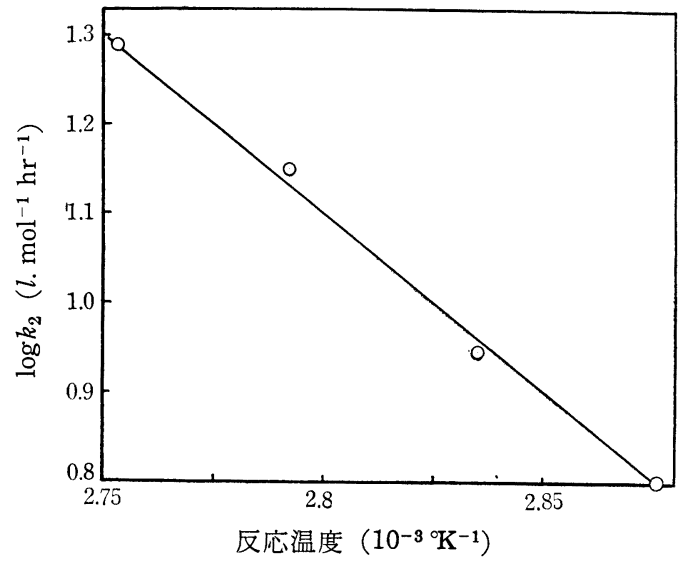

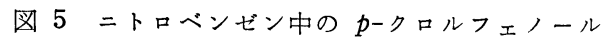
の反応の温度変化

$[\mathrm{P}]_{0}=[\mathrm{E}]_{0}=0.500 \mathrm{~mol} / \mathrm{kg}$, 触媒 $\phi \mathrm{ONa}$

結果はバラッキが大きいが，見掛けの活性化エネルギーは 18.2 $\mathrm{kcal} / \mathrm{mol}$ ，活性化エンタルピーは $18.6 \mathrm{e} . \mathrm{u} . / \mathrm{mol}$ と計算される。

表 9 にグリシドアミドと置換フェノールの反応の結果を示し, その Hammett プロット（図6 ) は, 前述のように分析困難のた めバラッキが大きいが， $\sigma>0$ の領域ではほぼ直線となり， $\rho$-值 は $-1.6 \pm 0.2$ となる。

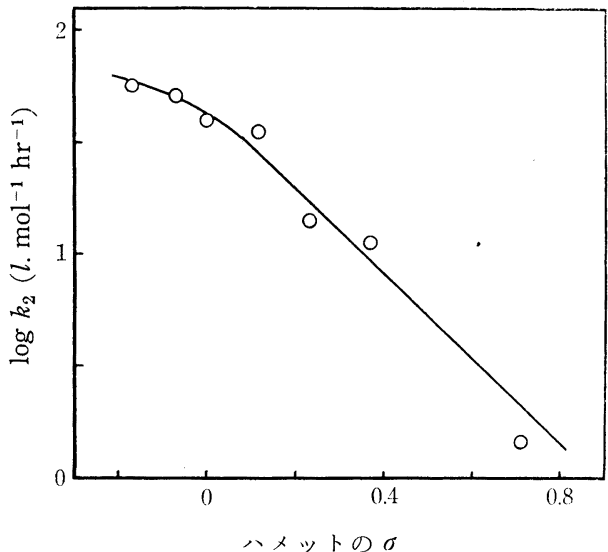

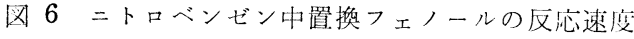
$[\mathrm{P}]_{0}=[\mathrm{E}]_{0}=0.500 \mathrm{~mol} / \mathrm{kg}$, 触媒 $\phi \mathrm{ONa}$, 反心温度 $84.5 \mathrm{C}$

\section{4 考察}

本報のグリシドアミドと置換フェノールとの塩基接触開環反応 の結果を既報のグリシジルエーテル5), 牤よびスチレンオキシド6) の結果と比較して表 10 に示した。

ナトリウムフェノキシドを触媒とするグリシドアミドのブタノ 一ル中の反応の活性化エントロピー拉よび活性化ェネルギーは, 避離イオン機構で反応するニトロベンゼン中，第三アミンを触媒
とするグリシジルェーテルとほぼ等しく，㯰換フェノールとの反

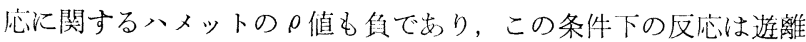
イオン機構［I］で進行するものと考兄られるしかし，二トロ ベンゼン中, ナトリウムフェノキシドを触媒とする場合, スチレ ンオキシド拉よびフェニルグリシジルェ 一テルでは速度式がエポキシド，塩基触 媒拉よびフェノールの 3 次の式で示され， $\rho$ 值が正で 3 分子錯体機構 [II] または 環状エーテルの酸素原子と置換フェノールとの水素結合の寄与を 考える機構 [ㅍ]］が考えられたのに対し，グリシドアミドの反忘 では同一の触媒・溶媒系で速度式は触媒扣よびェボキシドの 2 次 の速度式で示され， $\rho$ 值も負で，少なくとも見掛的上遊離イオン 機構が適用できるという異常な現象が認められた。<smiles>CC1CCCCC1OCCO</smiles>

[ I ]

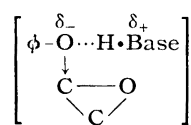

[II ]

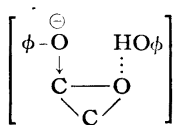

[III ]
表 10 各種エポキシドの比較

\begin{tabular}{|c|c|c|c|c|}
\hline & $\begin{array}{c}\text { エポキシド } \\
\text { 置換基の } \sigma^{*}\end{array}$ & $\begin{array}{c}\mathrm{O}^{\prime}{ }^{-\mathrm{CONH}_{2}} \\
1.320\end{array}$ & $\begin{array}{c}\mathrm{O}^{\prime-\mathrm{CH}_{2} \mathrm{O} \phi} \\
0.850\end{array}$ & $\begin{array}{c}{\overline{O^{\prime}}}^{-\phi} \\
0.600\end{array}$ \\
\hline & 速 度 式 & $k_{2}[\mathrm{C}][\mathrm{E}]$ & $k_{3}[\mathrm{E}][\mathrm{C}][\mathrm{P}]$ & $k_{3}[\mathrm{E}][\mathrm{C}][\mathrm{P}]$ \\
\hline 3 体 & 溶媒・触媒 & $\left.\phi \mathrm{NO}_{2}-\phi \mathrm{ONa}^{\mathrm{d}}\right)$ & $\phi \mathrm{NO}_{2}-\phi \mathrm{ONa}$ & $\phi \mathrm{NO}_{2}-\phi \mathrm{ONa}$ \\
\hline 分機 & 相 対 速度 & 83 & 1 & 0.1 \\
\hline 子粠 & $E\left(90 \sim 120^{\circ} \mathrm{C}\right)$ & $20.6^{\mathrm{a})}$ & $22.7 \mathrm{~b})$ & 16. $8 \mathrm{~b})$ \\
\hline 鐫 & $\Delta S \neq$ & $-18.5^{a)}$ & -22.4 & -26.5 \\
\hline & $\boldsymbol{\rho}$ & -1.6 & $\begin{array}{l}\left.+0.1^{c}\right) \\
(+0.7)\end{array}$ & +1.1 \\
\hline & 速 度 式 & $k_{2}[\mathrm{C}][\mathrm{E}]$ & $k_{2}[\mathrm{C}][\mathrm{E}]$ & $\left(k_{0}+k_{2}[\mathrm{C}]\right)[\mathrm{E}]$ \\
\hline & 溶媒・触媒 & $\mathrm{BuOH}-\phi \mathrm{ONa}$ & $\phi \mathrm{NO}_{2}-\mathrm{NBu}_{3}$ & $\phi \mathrm{NO}_{2}-\mathrm{NBu}_{3}$ \\
\hline 離機 & 相刘速度 & 45 & 1 & 0.2 \\
\hline 1構 & $E$ & 20.6 & 22.4 & 12.5 \\
\hline オ & $\Delta S \neq$ & -9.5 & -9.1 & -35.2 \\
\hline & $\rho$ & -0.95 & -0.80 & $\geq 0$ \\
\hline
\end{tabular}

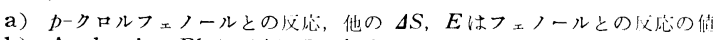

b) Arrhenius Plot がLに浓となる。

c）キシレン川の応の值

d）グリシドアミドの反忘は買常

ニトロベンゼン中, エポキシドとフェノールの酸素原子との水 素結合の強さを，フェノールの $\nu_{\mathrm{O}-\mathrm{H}}$ 会合バンドで測定するとき， 2,3-エポキシブタン拈よびスチレンオキシドのよ5に，置換基の $\sigma^{*}$ が大さい置換 エチレンオキシドでは， $3530 \mathrm{~cm}^{-1}$ の非会合水 酸基の吸収のほかに，3300～3400 に会合水酸基の吸収が現われ るのに対し， $\sigma^{*}$ の小さい置換エポキシドであるエピクロルヒド リン，フェニルグリシジルェーテルでは会合水酸基の吸収がほと んど認められない。グリシドアミドの場合はアミドの $\nu_{N-11}$ の吸 収のためこの領域の測定はできないが，エポキシドの塩基性はほ ぼの゙と值線關係にあり ${ }^{11)}$ ，したがって，フェニルグリシジッェ 一テルよりの゙の大きいグリシドアミドでは水素絬合は活とんど 然视でき，機棈 [III] の関与は考学られない。

ニトロベンゼン中，スチレンオキシドとフェノールの水菜絬合 による会合は少し認められ，このためフェノキシドのイオン化が 容易なトリーnーブチルアミン触媒反応の場合でも 0 はほぼ 0 とな

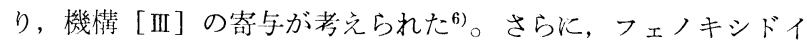
オンのイオン化が困難なナトリウムフェノキシド触媒反応では $\rho$ が +1.1 と增大し，この增分はグリシジルェーテルの反忘の場

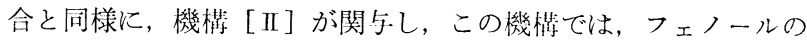

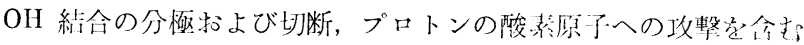

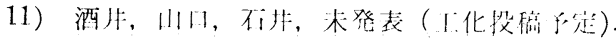


ので $\rho$ は正となると考えた6)。

$$
\begin{aligned}
& \phi \mathrm{OH}+\mathrm{Base} \rightleftarrows[\phi \mathrm{OH} \cdot \mathrm{Base}] \rightleftarrows \phi \mathrm{O} \ominus+\mathrm{H} \cdot \mathrm{Base}(\mathrm{t}) \\
& +n E \downarrow_{\downarrow} \downarrow+E \downarrow^{k_{c}}[\mathrm{~N}]+E \downarrow_{k_{i}}^{[\mathrm{V}]}
\end{aligned}
$$

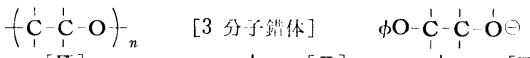

$$
\begin{aligned}
& \text { [V] } \quad \downarrow k_{f}[\mathrm{II}]+\left.P\right|_{\vee} k_{e} \quad[\mathrm{MI}] \\
& \phi \mathrm{O}-\stackrel{\prime}{\mathrm{C}}-\stackrel{\mathrm{C}}{\mathrm{C}}-\mathrm{OH}+\mathrm{Base} \quad \phi \mathrm{O}-\mathrm{C}-\mathrm{C}-\mathrm{CH}+\phi \mathrm{O} \theta
\end{aligned}
$$

[иII] [VII]

ナトリウムフェノキシドを触媒とするニトロベンゼン中のグリ シドアミドと，羁換フェノールの反応の異常な反応性の原因は明 確ではないが，グリシドアミドでは強力な電子吸引基でまるアミ ド基のためオキシラン環の求電子性が著しく増大し，エポキシド とフェノキシドイオン対との反応 $\left(k_{c}\right)$ よりも雄離フェノキシド イオンとの反応 $\left(k_{i}\right)$ がより大きく促進されるか，アミド基の活 性水素がプロトン性溶媒として作用し，イオン反応を促進するも のと推論される。

第三アミンを触媒とする場合，反応溶媒がキシレン，ニトロベ
ンゼン，あるいは n-ブタノール中のいずれる，グリシジルェー テル5)， スチレンオキシド6)，その他の一般のエポキシドとフェ ノールの反応では 1:1 開環付加生成物 [UII] 学生成した。しか し，グリシドアミドの場合はいずれの溶媒中でも $1: 1$ 生成物は 生成せず，ポリ(グリシドアミド)を生成したため，フェノールの 付加開環反応速度は測定できなかった。同一反応条件下，ナトリ ウムフェノキシドを触媒とする場合は重合は起こらず，したがっ て $k_{i}<k_{e}$ であり, このことはフェノールが酸性であることより, 妥当である。第三アミンを触媒とする場合はフェノールが共存す る場合も，共存しない場合も重合が扔こり，したがって重合はグ リシドアミドと第三アミンの反応で開始され，また，生長の活性 末端はフェノールにより不活性化されない $\left(k_{e}=0\right)$ と考光られ る。このように，グリシドアミドの反応における第三アミン触漤 の異常な重合活性は與味深いが，その詳紼は後ほど検討したい。

(本研究は昭和 39 年 11 月, 日本化学会東海支部大会で講演 した）

\section{フタル酸カリゥムの転位反応における触媒*1}

(炤和 41 年 1 月 6 日受理)

千葉耕司・村上 毅 臣*2

フタル酸カリウムを炭酸ガス加圧下で $440^{\circ} \mathrm{C}$ に加熱してテレフタル酸カリウムを製造するとき酸化覀鉛, 酸化カドミウム, 一酸 化鉊および四三酸化鉄が顕著な触媒効果をしめし，ことに酸化カドミウムは常圧下でも顕著な触媒能を有する。これらはいずれも 炭酸塩を形成することができ；かつ Nernst の近似式から算出した炭酸ガスの平衡圧 $\left(440^{\circ} \mathrm{C}\right)$ は比較的高いことから炭酸がス加 正は触媒効果と関連するように思われるが，酸化亜鉛については加熱時炭酸ガスの吸収が認められない。塩化亜鉛捛よび硫酸亚鉛 も影著な触媒能を有する。これらはフタル酸カリウムと反応しフタル酸亜鉛カリウムとして原料中に混合され，一部はテレフタル 酸塩へ転位するが，大部分は加熱時に分解する。同様にフタル酸亜鉛を触媒として添加するときもフタル酸覀鉛カリウムを生ずる が，一部はフタル酸亚鉛のままで漉入する。フタル酸西鉛も加熱時に分解し酸化亜鉛を生ずると考えられる。酸化亜鉛の触媒能は 他物質との混合によって阻害されることはすくない。

\section{1 緒 言}

合成䋐維原料としてのテレフタル酸の需要は最近急激に増加し ているが，その製造法の一つとして西独の Henkel 社の発明にな るヘンケル法 ${ }^{1,2,3)}$ がある。

発明は主としてフタル酸カリウムを $340 \sim 500^{\circ} \mathrm{C}$ に加熱してテ レフタル酸カリウムを得るものであるが，無触媒下では十分な収 率をあげ得ないので，有效な触媒を使用することが肝要である。 カドミウム化合物を主体としたこの穗の研究は従来多く発表され ている ${ }^{4,5)}$ 。

本報では工業的に有利な触媒を見出す目的から単一もしくは混

*1 本報を「ベンゼンカルボン酸塩の転位反心に関する研究 (第1 報)」とする.

*2 Takeomi MURAKami, Kōji CinBA 川㥓化成工業株式 会社研究部：川崎市大邩河原

1) 日本特許 No. 226094 .

2) 日本特許 No. 229934 .

3) 日本特詐 No. 230345 .

4) Y. Ogata, J. Am. Chem. Soc., 79, 6005 (1957).

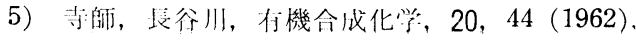

合触媒を使用し，主としてテレフタル酸収率の変化を調べ，また 触媒作用についても若干の知見を得た。

\section{2 実 験 方 法}

\section{$2 \cdot 1$ 転位反応}

$2 \cdot 1 \cdot 1$ 試料 無水フタル酸 $1 \mathrm{~g} . \mathrm{mol}(148.1 \mathrm{~g})$ を熱水 1000 $\mathrm{m} l$ に溶解し, 水酸化カリウム水溶液 $(\mathrm{KOH} 112.2 \mathrm{~g} /$ 水 $500 \mathrm{ml})$ を徐々に注加して溶液の $\mathrm{pH}$ を 7.8 とする。この溶液をはじめ 金網上弱い直火で加熱濃縮し，女め状を呈した頃，油浴上 $140^{\circ} \mathrm{C}$ で蒸発乾固する。これを十分に粉砕し，空気浴中 $140^{\circ} \mathrm{C}$ に長時間 保持して原料フタル酸カリウムとした。

所要量のフタル酸カリウムをとり，ほぼ同量の水を加えて加熱 溶解する。これをかきまぜながら，あらかじめ乳鉢で十分にすり つぶした触媒を少しづつ加光, 先の方法に準じて蒸発乾固して粉 砕し, さらに空気浴中 $140^{\circ} \mathrm{C}$ で乾燥後, 試料とした。

なお，無水フタル酸は純度 $99.9 \%$ 以上のものを使用し，その 他の試薬は市肘の試薬 1 級品をそのまま使用した。

$2 \cdot 1 \cdot 2$ 反応操作 試料 $21.20 \mathrm{~g}$ を, 硬質ガラス製円筒状容器 (肉厚 $1 \mathrm{~mm}$, 内径 $37 \mathrm{~mm}$ ) に称取し, 底を軽くたたさながら均 